\title{
環境問題を解決する社会環境とそれを支える新たな技術
}

\section{Social Environment for Solving Environmental Problem and New Technology}

環境調和型実装技術委員会

\section{1. 環境問題}

大きな課題を持つ時代となってきた。一つは“地球温暖 化対策”であり，温暖化の原因の一つには二酸化炭素 $\left(\mathrm{CO}_{2}\right)$ 排出が起因していると言われているが，一方で何らかの原 因で温暖化して海中などに溶け込んだ $\mathrm{CO}_{2}$ が排出して増加 するという説もある ${ }^{1)}$ 。

どちらの説にせよ, 産業革命以来, 表 1 のように地球大 気の成分の中で $\mathrm{CO}_{2}$ 含有量が図 1 に示すように年々, 増加 している点である2)。2030 年には, 550 ppm まで増加が予 想されている。

表 1 . 地球大気の成分

\begin{tabular}{|c|c|c|c|}
\hline \multirow{2}{*}{\multicolumn{2}{|c|}{ 気 体 }} & 質量比 & 体積比 \\
\hline & & \multicolumn{2}{|c|}{$\%$} \\
\hline 窒 & $\mathrm{N}_{2}$ & 75.35 & 78.08 \\
\hline 酸 & $\mathrm{O}_{2}$ & 23.07 & 20.95 \\
\hline アルゴン & $\mathrm{Ar}$ & 1.283 & 0.934 \\
\hline 水蒸気 & $\mathrm{H}_{2} \mathrm{O}$ & 0.330 & \\
\hline 二酸化炭素 & $\mathrm{CO}_{2}$ & 0.054 & 0.039 \\
\hline オゾン & $\mathrm{O}_{3}$ & 0.00064 & $0.000007>$ \\
\hline
\end{tabular}

既に $400 \mathrm{ppm}$ を超えた状態で， $\mathrm{CO}_{2}$ の排出削減が世界的 に高まる中で，今世紀末までにほぼゼロにする必要がある ことも指摘されており, 気候変動対策は契緊の課題であ り, ここに「低炭素社会」の構築が叫ばれるようになって きた。

さらに第二の課題は, “資源・エネルギ問題”である。増 え続ける人口に対して残念ながら限られた地球号なのであ る。

1700 年 6.4 億人であった世界人口が, 今や 2011 年に 70 億人となり， 2025 年には約 81 億人, 2050 年には, 約 95.5 億人の人口が予測されている ${ }^{3)}$ 。

まさに人口爆発である。地球も狭くなってきているので ある。資源・エネルギは, いずれは枯渇する問題を抱えて いる上に人口増に対する対応を今後，どうするかにある。

\section{2. 課題に対する解決アプローチ}

以上, 二つの課題に対しての解決する一つのアプローチ について述べる。

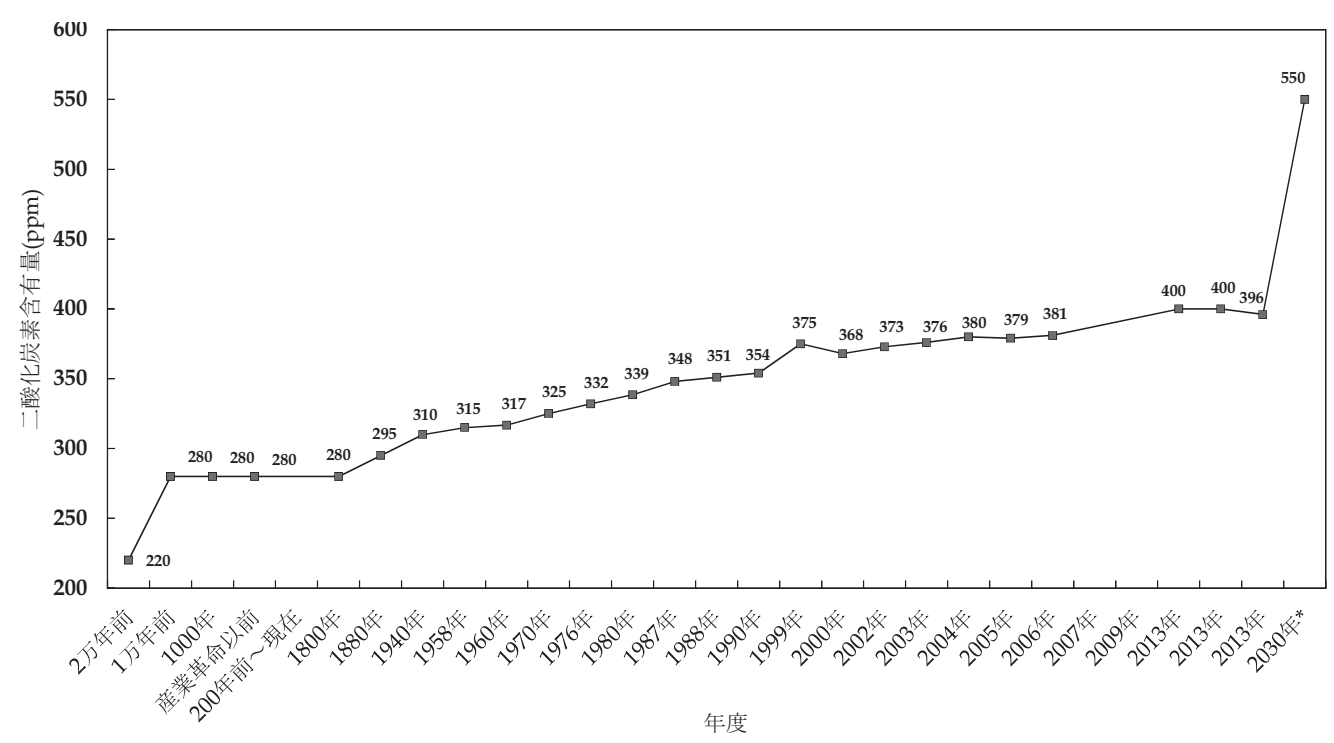

図 1. 二酸化炭素含有量の推移 


\section{1 エネルギと効率化}

エネルギ不足対策にエネルギを如何に効率良く利用し， さらに活用されていない資源を有効活用してエネルギに変 換することも大事である。かつ, 低消費エネルギ社会の構 築への対応も重要な課題となってきた。

高効率化を達成するために日本ではトップランナー方式 が採用されて大きな効果をあげているのは周知の通りであ る。日本のみならず国際的に高効率化規制も始まりつつあ る。

また，今までは化石資源によって得ていたエネルギも 「水力発電」,「風力発電」,「太陽光発電」,「太陽熱発電」, 「地熱発電」,「バイオマスガス発電」,「波力発電」,「振動発 電」,「排熱温度差発電」などを使用した再生可能エネルギ へのさらなる転換も重要な課題となってきた。

持続可能社会を構築するためには，一つには低消費エネ ルギの取組みは必須のアイテムでもある。産業用エネルギ 消費抑制のニーズが拡大し, 省エネ, 節電などが重要なポ イントであると指摘されている。

例えば，ビルなどの空調でインバー夕を使用する場合と 使用しない場合を比べると効率化の効果もあって電力料金 が 20〜 50\%も低減できるといった事実である。

インバータ装置には 1965 年頃にサイリス夕を利用したも のが商品化されて以来， ジャイアントトランジス夕（パ ワーバイポーラトランジスタ) が開発され, 現在は絶縁 ゲートバイポーラトランジスタ (IGBT) の主回路を用いた装 置が一般的になっている。

さらに次世代パワーデバイスとして期待されているのが $\mathrm{SiC}$ (炭化ケイ素, シリコンカーバイト), GaN（窒化ガリ ウム，ガリウムナイトライド）の次世代材料であり，これ らが採用されるようになり, 既に電車, エレベータ, エア コンなどに搭載されるまでになってきた。

電気エネルギ利用の高効率化, 環境負荷低隇への要請が 強く, 発電から消費までの電力フローの中で, 電力変換技 術の占める役割は大きく, パワーエレクトロニクスの革新 が必須となり，パワーデバイスに熱い視線が注がれている のも当然とも言える。

電力変換で $8 \sim 10 \%$ の電力が失われており，その総量は 国内で 1 年間に約 800 億 $\mathrm{kW}$ 時となると言われ，これは原 子力 8 基分の電力が失われていることを意味する。これを 効率化によって少しでも減少させれば，資源・エネルギを その分，使わなくてすむことになる。

新たな取組みとして 2014 年 4 月に策定されたエネルギ基 本計画で定められたものに水素エネルギの導入推進があ る。エネルギの安定供給, 経済効率性の向上, 環境への適 合, 安全性 $(3 \mathrm{E}+\mathrm{S})$ の観点から検討され始め「水素社会の構 築」も目指している。水素社会実現に向けた 3 段階で検討 されている。

第 1 段階は“エネフアーム”で，家庭に普及し，累積設
置台数も 10 万台を超え，先ず「水素」を身近なものに，そ して第 2 段階として“燃料電池自動車”が販売されたこと により，水素インフラを整えることで水素ステーションの 建設が始動している。第 3 段階では “大規模発電”で, 量 的な拡大を狙って進められている。

水素・燃料電池関連の市場規模は，我が国だけでも 2030 年に 1 兆円程度, 2050 年に 8 兆円程度に拡大するとの試算 がされており，今後 10〜35 年間で大きく成長する分野と期 待されており，産業振興の意味でも期待されている。

また，人口増に対して，エネルギ問題のみならず食料自 給の問題が浮上してきている。ただ単にエネルギや食料を 消費するだけではなく，食料においては，如何にして収穫 量をあげるかにある。IT を駆使してあらゆる情報を収集し ての効率よい植物工場として位置付けた取組みも必要であ る。農業の工業化も今後の大きな検討課題の一つである。

さらにエネルギについては創エネや畜エネをも配慮しつ つ新たな技術開発を実施しなければならない分野でもある。

\section{2 新たな社会環境とその対応}

東日本大震災とその後に発生した大津波によって福島第 一原子力発電所は被害を受けて電力を供給することが不可 能となった。この事故は, 原子力発電所の安全性に関する 国民の危機意識を高め，国内の多くの原子力発電所が安全 性の確認のために運転を停止するという事態に至ってし まった。

このため必要な電力を十分に供給することが困難とな り，その後，節電対応をしたものの計画停電，鉄道運行本 数の削減など被災地だけでなく，多くの国民が電力供給の 不足による不自由な生活を強いられ，エネルギの確保の重 要性を再認識させた。これほど重要性を認識させた例は少 ない。

東日本大震災を契機に原子力発電による電力供給は，今 後を展望すると将来的には段階的に縮小されていくものと 想定される。

しかし，一方で，それを補う新エネルギ技術が十分に開 発されていない状況でもある。再生可能エネルギへの熱い 視線が注がれているものの，まだ，原子力発電を補える程 のインフラは整っていない状況である。つまり，遅れてい る分野である。

この間にも年々, 電力需要は増大の一途をたどり, 特に パソコンや携帯情報端末に代表される情報通信機器の普 及，情報処理したデー夕を保存するデータセンターの普及 などにより電力消費量の増加傾向が予測されている。温暖 化抑制の観点からも情報処理システムの消費電力低減が急 務となっている。グリーン IT が叫ばれている点はここにあ

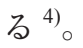

\section{これらを想定して今後の社会を展望してみると}

1. 安全安心な社会の構築

2. 快適な社会の構築 
3. 持続可能な低エネルギ消費社会の構築

4. 快適で安全な車社会の構築

などが必要となってくる。

このような社会となると個別対応ではなく, 総合的な取 組みが必要で, 例えばスマート・シティやスマート・コ ミュニティなどが想定され, 既存の概念だけではなく, 低 消費エネルギが達成できて, ゼロ・エネルギ・ビルディン グ (ZEB), ゼロ・エネルギ・ハウス $(\mathrm{ZEH})$ などを達成する ことは勿論, 今までの「省エネ」程度の考えではなく,「ゼ ロエネ」を念頭にして取り組むことが必要となってくる。

地域でエネルギの地産地消するスマート・シティやス マート・コミュニティの実現が重要となってくる。

日本では全国 4 地域での実証実験によって，スマート・ コミュニティの構築に必要な高度なエネルギマネジメント 技術や機器間の通信インターフェイスの確立などが検討さ れている。

産業, 暮らし, 社会を大きく変えていく IT の技術革新と 実世界・サイバー空間の情報連携がもたらすサイバーフィ ジカルシステム $(\mathrm{CPS}=\mathrm{Cyber}$ Physical System) とモノのイン ターネット (IoT=Internet of Things) を支えるキーデバイスと して各種センサー, センサーの複合化などは, これから早 急に構築していくことが重要である。

IoT や機械同士が繋がる M2M (Machine to Machine) が本 格化するに当たって多くの情報を正確に負担なく収集する センサーは重要な位置付けを占めるようになってきた。

IoTの本格化により，あらゆるモノが有機的につながる 新たなネットワーク社会が到来し, 人々の暮らし, 産業な どを大きく変革していくことが予想されている。

現在, システムが構築されていてもそのシステムの 85〜 90\%は，ネットワークに繋がってなく，これからは，シス テムを如何にして接続して, 一体化して効率化を図ってい くかにある。そのことによって環境対策の一助になってい くと予想される。

センサネットワークに使用されるセンサデバイスの共通 的な課題となる無線通信機能, 自立電源機能, 超低消費電 力機能の搭載を実現する先進的なセンサーの開発が急務で あり, センサネットワークの導入によって環境計測やエネ ルギ消費量などの把握 (見える化), エネルギ消費量の制 御・節約 (最適化) により, 低炭素社会の実現に寄与する ことになる。

2020 年に 500 億台のデバイスがネットワークに接続され るという予測があり, こうした端末をすべて対象となって モノが繋がっていく時代が到来する。つまり, 農業セン サーやインフラモニタリング用機器, 自動運転車, ロボッ トなど, 低遅延あるいは超省電力が必要とされる端末であ る。

そのため 5 世代通信システム $(5 \mathrm{G})$ の確立が要望されてい る。 $5 \mathrm{G}$ では, 多様な要求に応えられるような新しい無線イ
ンターフェースが規定される見达みで, 2020 年までには構 築される予定である。

自動車はエレクトロニクス化が進展し, 各種制御, 通信 システムなど搭載されているセンサーは今や 1 台当たり 100 個を超え, 自動車の安全, 安心, 快適に重要な役割を果た している。

走行安全およびエネルギ効率向上のニーズを捉え, 超音 波センサー, MEMS (Micro-Electromechanical Systems) 慣性 カセンサー, 電流センサーなどが採用され, 自動運転シス テムや先進運転支援システム (ADAS) の実用化，普及に向 けて，MEMS 技術や超音波技術を応用したセンサーによる 展開が面前に迫ってきた。

センサー技術の応用が生活の中のさまざまな場面で急速 に広がっている。環境や動きの情報を捉える高性能なセン サー技術の開発が進んだことに加え, 小型バッテリで長時 間動作可能な無線通信技術や信号処理技術，さらに多様な 情報の蓄積・解析を可能にするクラウドコンビューティン グの技術の普及が進んでいる。

それに伴い,さまざまな機器に搭載されるセンサーの種 類と数が増大し，センサーが取得した情報を複数組み合わ せて新たな意味づけを行うなど, アプリケーション技術が 大きく進歩している。

こうした技術は, モバイル機器から自動車や産業機器 へ，また積極的な生体情報の取得するへルスケアへの活用 などが，急速に拡大していくことが予想される。

環境対策を加味しての変わりつつある社会環境を実現す るためには新たな技術開発が必要であるのは言うまでもな い。次に，その対応技術の一例を紹介する。

\section{3 軽量化による効率化と異種材料接合技術}

日本の総エネルギ消費の $24 \%$ を輸送機器が占め, うち自 動車は $89 \%$ を消費しており，自動車の然費改善が大きな テーマとなっている。航空機産業でも同様な動きがある。

また，自動車産業に対する環境規制の強化が世界的に進 んでおり, 今後, 数年にわたり 2 倍以上の燃費改善を迫ら れている。

一般的に, 軽量化効果は $100 \mathrm{~kg}$ の重量減で $+1 \mathrm{~km} / \ell$ の燃 費改善, および $15 \mathrm{~g} / \mathrm{km}$ の $\mathrm{CO}_{2}$ 排出量削減に繋がると言わ れている。燃費改善には, 当然ながらパワートレインなど の改善のほか, 車体の軽量化が有効な手段となっている。

車体の軽量化には, 従来の鋼材の改良だけでは限界にき ており, マルチマテリアル化が「要の技術」となっている。

マルチマテリアル化は, 軽量材料であるハイテン鋼, ア ルミニウム合金, マグネシウム合金などの金属材料やさら に樹脂とその複合材料である CFRP (Carbon Fiber Reinforced Plastics) などの必要な機能を有する材料を局所的に適材適 所で組み合わせて使用し, 車体全体としての軽量化効果を 高めようとするものである。図 2 に自動車の各部素材の今 後の使用比率の見达みを示したものである。従来鋼から新 
たな材料・複合材料の応用展開が予想されている。

マルチマテリアル化の実現には，材料開発のみならず異 種材料接合技術が重要になっている。異種材料接合とは, 金属と樹脂, 異なった金属同士, 異なった樹脂同士など を，ボルトや接着片なしで接着，接合する技術である。

経済産業省の 2013 年度未来開拓研究プロジェクト「革新 的新構造材料等技術開発」でも, 新構造材料の開発と併せ て異種材料接合技術の開発が主要課題の 1 つとして取り上 げられており, 異種材料接合技術開発は重要なポイントと なる。

また，エレクトロニクス実装の分野での異種材料接合の 例を挙げると, スマートフォンなどのモバイル通信系分野 では, 樹脂と金属の異種材料接合技術の導入が進んでいる。

スマートフォンには, 3G, LTE, WiFi, Bluetoothなどさ まざまな通信方式が採用されており，アンテナの設計や配 置が通信特性に大きく影響する。金属筐体は, 強度確保, 高級感を出すデザインという観点では優れた特長を持つ が, 金属だけでは無線の電波を通さないため, 部分的に樹 脂と組み合わせて, 必要なところだけ電波の通り道を確保 する方法が用いられている。

接着剂やねじ, 単純なインサート成形では, 薄型軽量, 強度やデザイン性を確保したスマートフォンは実現できな い。そこで異種材料接合技術を使って, 金属部材に樹脂を インサート成形することによって，接着剤やねじを使った 時に必要なエリアや工程を削減でき, 高強度で樹脂と金属 を接合することができる。

ここで用いる異種材料接合の技術は, 金属表面に薬品や レーザーなどで微細な凹凸を設けてアンカー効果で樹脂と の強度を確保する方法, 金属と樹脂を化学的な結合で強度 を確保する方法などがある。

もう一つ，エレクトロニクス実装の分野での異種材料接 合として耐環境 $\mathrm{RFID}^{6)}$ を紹介する。ユニフォームなどの服 にRFIDを取り付け，無線通信によって管理を行うことが あり，RFIDにはさまざまな耐環境性が求められる。着用， 洗濯機やドライクリーニングでの洗濯, アイロンがけをす るので, 耐水性, 耐折性, 耐圧性, 耐薬品性, 耐熱性が求

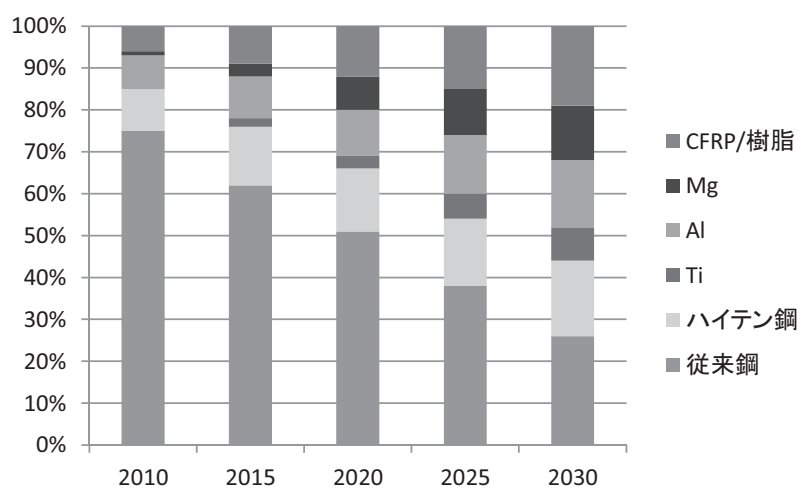

図 2. 自動車の各部素材の使用比率見込み ${ }^{5)}$
められる。また，医療や半導体などの製造に使うユニ フォームでは, オートクレーブで高温高圧による滅菌処理 をする場合があり，さらなる過酷な耐環境性が求められる。

これら要求に対応するため, 分子接合技術を用いて架橋 シリコーンゴムと架橋シリコーンゴムの間に PET フィルム 上に IC と金属アンテナの実装基板を封入し，中空封止構造 を実現した製品を図 3，図4 にそれぞれ示す。

分子接合技術は，高分子，七ラミックス，金属などの材 料を接合することができ，図 5 のように材料 A と化学反応 する官能基と材料 $\mathrm{B}$ と化学的に反応する官能基から構成さ れた 2 官能性化合物 X（分子接合剂）を用いて，材料 A と 材料 B 間を化学結合で接合する技術である。

分子接合技術の特徴としては，各材料表面に対して分子 接合剤を化学結合により導入し，材料の表面エネルギを分 子接合剤の表面エネルギへ変換し，界面を化学結合させる ことである。これにより，材料や接合条件の依存性を低減 することができる。また，化学結合は，通常の接着剤と被 着体に働く二次結合力より大きいので，十分な界面結合力

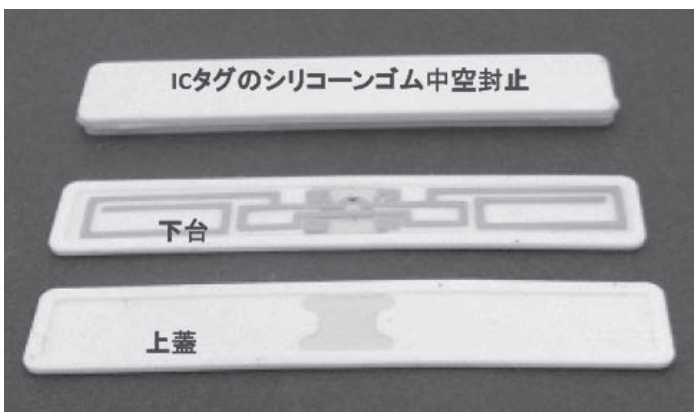

図 3. 耐環境 RFID

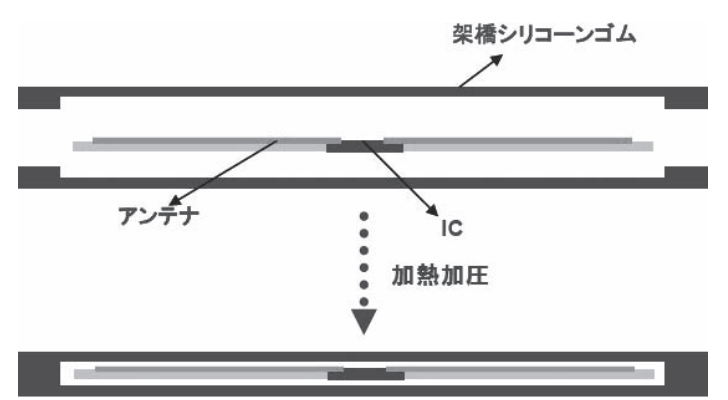

図 4. 耐環境 RFID の構造と接合プロセス

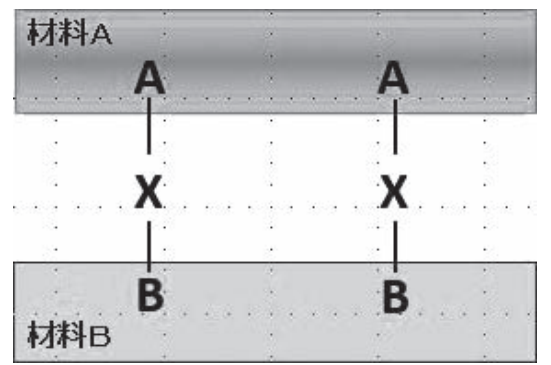

図 5. 分子接合技術のメカニズム 
を得ることができ, 環境が変化した場合でも信頼性の確保 ができる。

異種材料接合技術は, さまざまな原理, 手法があり, 特 に日本はこの分野で䪊的技術を有しているが，企業独自 の評価方法により取得したデータでは, 顧客の信頼を十分 に得ることが難しい状況にあった。

また，これまでも，せん断接着強度を測定する方法の評 価規格 ISO4586 はあったが, 接合面積が大きく, 高強度が 得られる異種材料接合技術では接合部分より弱い樹脂部分 が先に破断してしまい, 接合部強度の定量化が困難であっ た。

そこで, 産業技術総合研究所と日本プラスチック工業連 盟が, 経済産業省の支援を受け提案し, 異種材料複合体の 特性評価試験として表 2 に示すように 2015 年 7 月に国際規 格 ISO19095 シリーズとして承認された。

新規格では, 試験片形状の最適化や補助治具の使用によ り, 樹脂部分の破壊を防げるため, 強固に接合された樹脂 と金属複合体の接合界面の強度や耐久性を定量的, 客観的 に評価できる。日本が世界に先駆けて国際標準化を進めた ことにより, 日本の省エネルギ技術の国際競争力強化や, 優れたものづくり技術の差別化が進むと期待される ${ }^{7}$ 。

以上, 直面する環境問題の概要を述べ, 今後, 変わりつ つある社会環境を展望しながら, 新たな技術開発による対

表 2. 国際規格 ISO19095 シリーズ

\begin{tabular}{c|l|l}
\hline \multicolumn{1}{c|}{ 規格番号 } & \multicolumn{1}{|c}{ 規格名称 } & \multicolumn{1}{c}{ 概 要 } \\
\hline ISO 19095-1 & $\begin{array}{l}\text { Plastics - Evaluation of the adhesion } \\
\text { interface performance in plastic-metal } \\
\text { assemblies - } \\
\text { Part 1: Guidelines for the approach }\end{array}$ & $\begin{array}{l}\text { 樹脂一金属複合体の接合 } \\
\text { 部分の特性を評価する際 } \\
\text { の装や置や評価項目を規定 }\end{array}$ \\
\hline ISO 19095-2 & Part 2: Test specimens & $\begin{array}{l}\text { 試験片の形状や寸法など } \\
\text { を規定 }\end{array}$ \\
\hline ISO 19095-3 & Part 3: Test methods & $\begin{array}{l}\text { 初期特性を評価する際の } \\
\text { 試験方法を規定 }\end{array}$ \\
\hline ISO 19095-4 & $\begin{array}{l}\text { Part 4: Environmental condition for } \\
\text { durability }\end{array}$ & $\begin{array}{l}\text { 耐久性を評価する際の試 } \\
\text { 験方法を規定 }\end{array}$ \\
\hline
\end{tabular}

応の処方箋などを解説した。今後の環境対応の参考になれ ば幸いである。

$$
\begin{aligned}
& \text { 文責 } \text {.八甫谷明彦 } / \text { 東芝 } \\
& \text { 青木正光 } / \text { 日本環境技術推進機構 }
\end{aligned}
$$

(2015.11.17- 受理)

\section{文献}

1) 丸山茂徳：“『地球温暖化論』に騙されるな,” pp. 58-63, 講談社, 初版, 2008

2) http://ds.data.jma.go.jp/ghg/kanshi/ghgp/co2_trend.html

3) http://www.stat.go.jp/data/sekai/0116.htm

4) JEITA：“サーバーから始めるグリーンIT,” 2009

5）経済産業省産業技術環境局研究開発課：“革新的新構造材料 等技術開発説明資料, " 2014

6) 科学技術振興機構：“21 世紀型産業を岩手から「産学」で 発信,”産学官連携ジャーナル，7月号，2012

7) 日本電気制御機器工業会編：“国際標準は自分で創れ!, ” pp. 1-5, 日刊工業新聞社, 初版, 2009

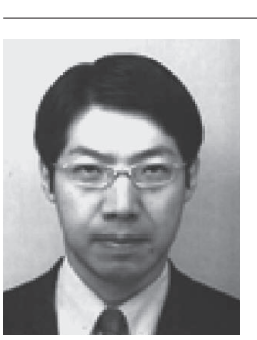

八甫谷明彦（はっぽうや あきひこ）

著者紹介

1990 年・岩手大学工学部資源化学科卒，同年東芝 入社

2010 年 $\cdot$ 博士（工学） 日本実装技術振興協会高 密度実装技術部会運営委員，エレクトロニクス実 装学会会員, 同環境調和型実装技術委員会委員長 現在・株式会社東芝セミコンダクタ\&ストレージ社

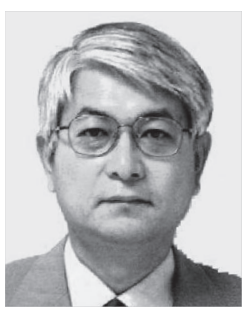

青木正光（あおき まさみつ）

1968 年九州工業大学工業化学科卒, 同年東芝入社 後, 東芝ケミカル, 東芝ケミカルョーロッパ社, UL-Japan, Nokia-Japan, 日本電子回路工業会 (JPCA) などで実装関連の材料開発から実装技術，製品安 全, 調達, 環境関係, 国際標準化活動 (IEC/TC91 WG6\&WG10 コンビナ）に携わる。現 特定非営利 活動法人日本環境技術推進機構, 現 特定非営利活 動法人サーキットネットワーク (C-NET), エレク トロニクス実装学会会員。 